\title{
PENGGUNAAN PROFILE MATCHING DAN FRAMEWORK CODEIGNITER DALAM PENGAMBILAN KEPUTUSAN PENERIMAAN KARYAWAN BARU DI LOKA MONITOR SPEKTRUM FREKUENSI RADIO PANGKALPINANG
}

\author{
Fitriyani $^{1}$, Elly Yanuarti $^{2}$, Yuranda ${ }^{3}$ \\ ${ }^{123}$ STMIK Atma Luhur Pangkalpinang
}

Article Info:

Dikirim: 16 Oktober 2019

Direvisi: 24 Desember 2019.

Diterima: 31 Desember 2019

Tersedia Online: 31 Desember 2019

Penulis Korespondensi: Fitriyani

STMIK Atma Luhur Pangkalpinang, Pangkalpinang, Indonesia

Email: fitriyani@atmaluhur.ac.id

\begin{abstract}
Abstrak: Peran sumber daya manusia (SDM) di Loka Monitor Spektrum Frekuensi Radio Pangkalpinang sangat berpengaruh dalam menentukan serta menghasilkan sumber daya manusia yang dapat mendukung mutu serta kesuksesan suatu organisasi. Dalam menentukan karyawan sering terjadinya penilaian yang berdasarkan subjektifias dan nepotisme. Bila dibiarkan dalam jangka waktu yang panjang hal tersebut dapat mempengaruhi kinerja sebuah organisasi sehingga berakibat pada kegagalan organisasi dalam mencapai tujuan. Dalam hal ini penulis mengusulkan penerapan metode Profil Matching dalam pengembangan sistem penunjang keputusan sehingga karyawan diseleksi berdasarkan kriteria tes wawancara, tes tertulis, tes praktek yang terdiri dari Microsoft word dan excel dan tes keahlian. Hasil dari pengolahan data alternatif yaitu pelamar 1 dengan N.S 4.9, pelamar 2 dengan N.S 2.7, pelamar 3 dengan N.S 2.4, pelamar 4 dengan N.S 3.4, pelamar 5 dengan N.S 3.8, Sistem penunjang keputusan yang dibangun menggunakan Framework codeigniter, dengan database MySQL, hasil yang di dapat dari sistem ini adalah mempermudah bagian SDM dalam mengolah data calon karyawan baru dalam mengolah data seleksi dapat dilakukan dengan cara yang professional dan transparan serta mempermudah bagian SDM dalam menghasilkan sumber daya manusia yang dapat mendukung mutu yang baik untuk jangka waktu yang panjang.
\end{abstract}

Kata kunci: sistem penunjang keputusan; penerimaan karyawan baru; metode profile matching; framework codeigniter; MySQL.

\begin{abstract}
The role of human resources (HR) in Radio Frequency Spectrum Monitoring Spectrum Pangkalpinang very influential in determining and producing human resources that can support the quality and success of an organization. In determining employees often the occurrence of judgments based on subjectiveias and nopotisme. If left in a long period of time it can affect the performance of an organization resulting in the failure of the organization in achieving goals. In this case the authors propose the application of Matching Profile method in the development of decision support system so that employees are selected based on the criteria of interview test, written test, practice test consisting of Microsoft word and excel and skill test. Results of alternative data processing are applicants 1 with NS 4.9, 2 applicants with NS 2.7, 3 applicants with NS 2.4, 4 applicants with NS 3.4, applicants 5 with NS 3.8, decision support systems built using codeigniter framework, with MySQL database, which in the can of this system is to simplify the human resources in processing data prospective new employees in the process of data selection can be done in a professional and transparent way and facilitate the human resources in producing human resources that can support good quality for a long period of time.
\end{abstract}

Keywords: decision support system; new employee acceptance; profile matching method; codeigniter framework; MySQL. 


\section{PENDAhUluaN}

Diera globalisasi saat ini, perkembangan teknologi informasi semakin maju menjadi faktor penting yang dapat dikatakan sangat berpengaruh bagi kehidupan manusia. Begitu banyak hal yang bisa dilakukan berdasarkan bantuan dari teknologi informasi, begitupun dengan adanya penggunaan aplikasi-aplikasi, segala proses yang rumit dan berskala besar dapat dipermudah dan dipercepat, proses perhitungan, percepatan pelaporan dan pencarian data-data akan semakin lebih mudah dan membuat keputusan-keputusan pun dapat dengan lebih mudah dibuat.

Pada dasarnya, tujuan seleksi dengan penerimaan karyawan untuk mendapatkan orang tepat untuk suatu jabatan tertentu, sehingga orang tersebut mampu bekerja secara optimal dan dapat bertahan di organisasi yang cukup lama. Meskipun tujuannya terdengar sangatlah sederhana, namun proses tersebut ternyata sangat komplek, memakan waktu yang lama , biaya tidak sedikit dan sangatlah membuka peluang untuk melakukan kesalahan dalam menentukan orang yang tepat. Terlebih bila seorang calon karyawan memiliki kemampuan yang tidak jauh berbeda dengan calonnya lain, maka dalam penentuanya terkadang sanggatlah subjektif.

Penelitian Analisis dan Perancangan Seleksi Pemilihan Pegawai Untuk Suatu Jabatan Menggunakan Metode Profile Matching yang dilakukan oleh Hartatik tahun 2013 [7]. Hasil dari penelitian tersebut didapatkan hasil perangkingan calon karyawan dengan melakukan perbandingan profil pribadi karyawan dengan profil jabatan yang bersangkutan.

Penelitian lain yang dilakukan oleh R.Prasetyo Agung Nugroho dan Purwanto tahun 2015 yang berjudul Rancangan Sistem Pendukung Keputusan Penerimaan Pegawai Menggunakan Metode Profile Matching [10]. Hasil dari Penelitian tersebut adalah ditemukan hasil perangkingan dengan menggunakan 3 aspek yaitu aspek Kapasitas Intelektual, Sikap Kerja, dan Perilaku. 3 aspek tersebut membantu dalam menerapkan pembobotan nilai pada tiap-tiap calon karyawan untuk menentukan perangkingan.

Berdasarkan 2 penelitian terkait menunjukkan adanya hubungan dengan penelitian yang telah peneliti lakukan yaitu menggunakan metode profile matching dan membantu dalam menentukan aspek untuk melakukan penyeleksian pegawai/karyawan untuk suatu perusahaan.

\section{METODOLOGI PENELITIAN}

\subsection{Model Pengembangan Sistem}

Dalam penelitian ini, pada model pengembangan iterative terdiri dari empat tahap yaitu planning, analisys, design, dan implementasi. [4]

1) Planning

Dalam tahap ini tahap planning atau persiapan menggunakan beberapa teknik pengumpulan data seperti:

a. Wawancara adalah suatu cara menumpulkan data dengan cara mengajukan pertanyaan langsung kepada pihak berwenang terkait dengan topik yang diambil.

b. Survey ialah pengumpulan data penelitian yang berdasarkan pada komunikasi antara peneliti dengan responden (objek yang diteliti).

c. Studi Pustaka yaitu mengumpulkan berbagai informasi terkait, mengumpulkan bahan dari sumbersumber buku, jurnal, seminar nasional yang berbentuk online, atau sumber yang berkaitan dengan topik penelitian.

d. Kuisioner

e. kuisioner adalah teknik pengumpulan data untuk memperoleh informasi yang relevan sesuai dengan tujuan penelitian.

f. Pengamatan

g. Sebuah studi atau pembelajaran yang dilaksanakan dengan sengaja, terarah, berurutan, dan sesuai tujuan yang hendak dicapai pada suatu pengamatan

2) Analisis kebutuhan perangkat lunak

Pada tahapan ini penulis melakukan analisa sistem yang berjalan, analisa kebutuhan sistem, analisa sistem usulan dan analisa metode Profile matching yang akan diterapkan pada sistem usulan. Pada tahapan analisa sistem berjalan dan analisa kebutuhan sistem, penulis melakukan observasi dan wawancara di Loka Monitor Spektrum Frekuensi Radio Pangkalpinang selanjutnya pada tahapan analisa sistem usulan penulis melakuan studi pustaka yang sesuai dangan sistem usulan yaitu Penggunaan Metode Profile Matching dan Framework Codeigniter Dalam Pengambilan Keputusan Penerimaan karyawan Baru Di Loka Monitor Spektrum Frekuensi Radio Pangkalpinang dan pada tahapan analisa metode Profile Matching penulis membuat bobot dan kriteria Calon Karyawan baru yang sesuai permintaan dari pihak Loka Monitor Spektrum Frekuensi Radio Pangkalpinang.

3) Design

Tahap ini, penulis akan merancang form antar muka pengguna sistem penunjang keputusan pemilihan pesrta didik baru dan database sesuai dengan kebutuhan sistem. Form yang akan dirancang diantaranya, antar muka pengguna web server, antar muka pengguna web user. 
4) Implementasi

Pada tahapan ini penulis mengaplikasikan perangkat lunak yang dibangun untuk digunakan oleh panitia penerimaan oleh Loka Monitor Spektrum Frekuensi Radio Pangkalpinang.

\subsection{Metode Pengembangan Sistem}

\subsubsection{Metode Object Oriented Programming (OOP)}

OOP (Object Oriented Programming) adalah suatu metode pemrograman yang berorientasi kepada objek. Tujuan dari OOP diciptakan adalah untuk mempermudah pengembangan program dengan cara mengikuti model yang telah ada di kehidupan sehari-hari. Jadi setiap bagian dari suatu permasalahan adalah objek, objek itu sendiri merupakan gabungan dari beberapa objek yang lebih kecil lagi. Pada tahap ini, penulis menerapkan metode pengembangan perangkat lunak menggunakan metode object oriented programming (OOP) yaitu pada Website.

\subsection{Alat Bantu Pengembangan Sistem}

\subsubsection{Tools Pengembangan Sistem}

Pada penelitian ini penulis menggunakan 2 diagram yang ada pada Unified Modeling Language untuk menggambarkan proses pembuatan aplikasi yang akan dibuat. Kedua diagram tersebut yaitu :[1]

\section{1) Use Case Diagram}

Use case Diagram merupakan sebuah teknik yang digunakan dalam pengembangan sebuah software atau sistem informasi untuk menangkap kebutuhan fungsional dari sistem yang bersangkutan. Use Case menjelaskan interaksi yang terjadi antara 'aktor' - inisiator dari interaksi sistem itu sendiri dengan sistem yang ada, sebuah Use Case direpresentasikan dengan urutan langkah sederhana.

2) Activity Diagram

Activity Diagram merupakan alur kerja (workflow) atau kegiatan (aktivitas) dari sebuah sistem atau menu yang ada pada perangkat lunak. Activity diagram juga digunakan untuk mendifinisikan urutan atau pengelompokkan tampilan dari sistem/user interface dimana setiap aktifitas dianggap memiliki sebuah rancangan antar muka tampilan serta rancang menu yang ditampilkan pada perangkat lunak.

\section{HASIL DAN PEMBAHASAN}

\subsection{Use Case Usulan}

1) Use Case Admin

Gambar 1 menunjukkan apa yang bisa dilakukan oleh admin pada sistem.

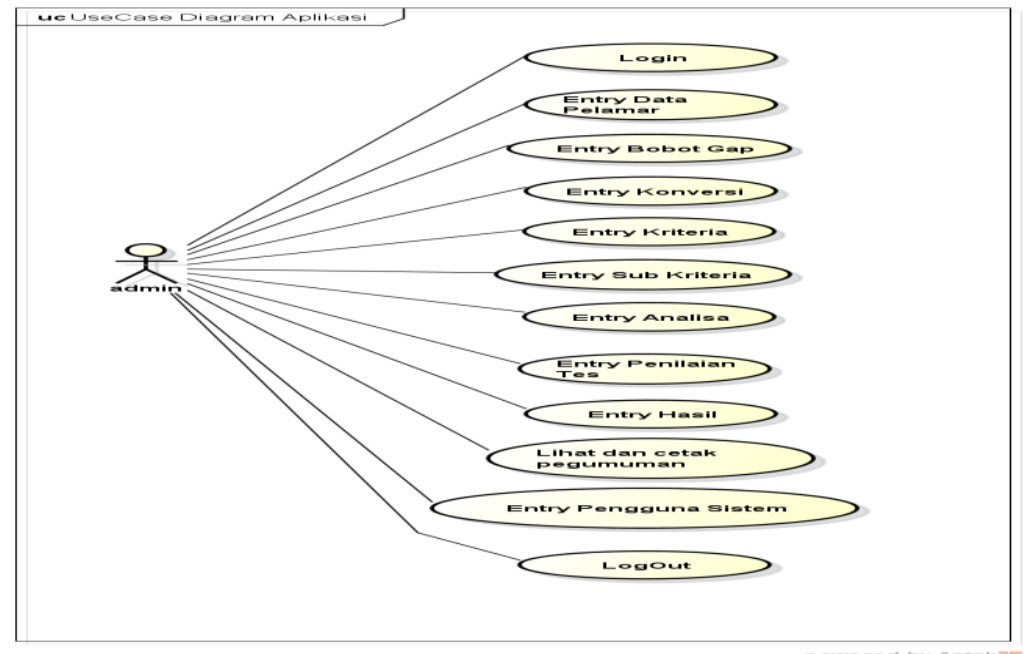

Gambar 1. Use Case Admin 
2) Use Case Pelamar

Gambar 2 menunjukkan apa yang bisa dilakukan oleh pelamar pada sistem.

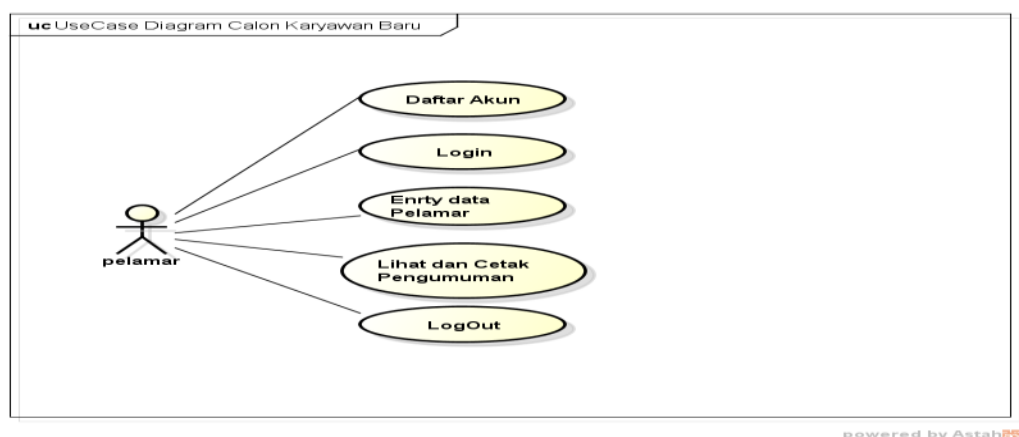

Gambar 2. Use Case Pelamar

3) Use Case Petugas Penguji

Gambar 3 menunjukkan apa yang bisa dilakukan oleh petugas penguji pada sistem.

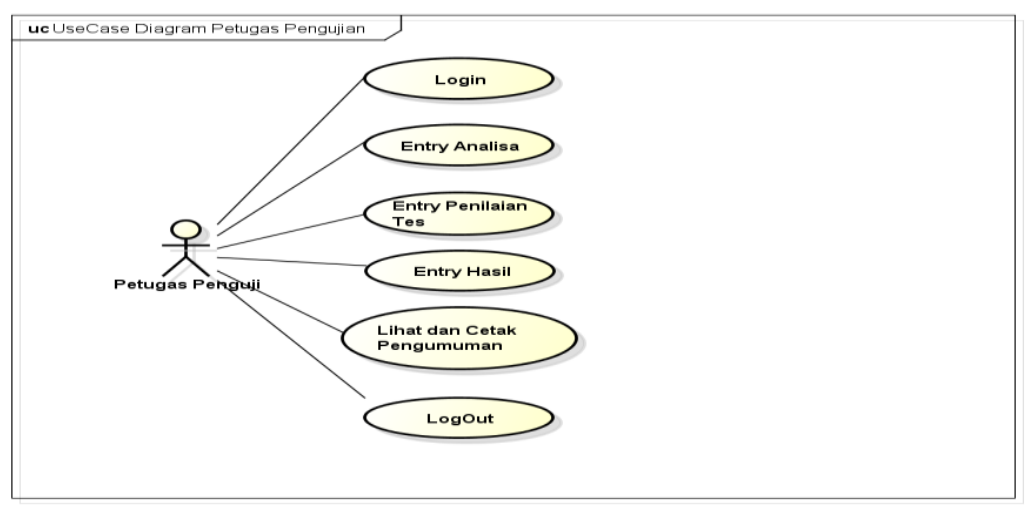

Gambar 3. Use Case Petugas Penguji

4) Use Case Kepala Loka Monitor

Gambar 4 menunjukkan apa yang bisa dilakukan oleh kepala loka monitor pada sistem

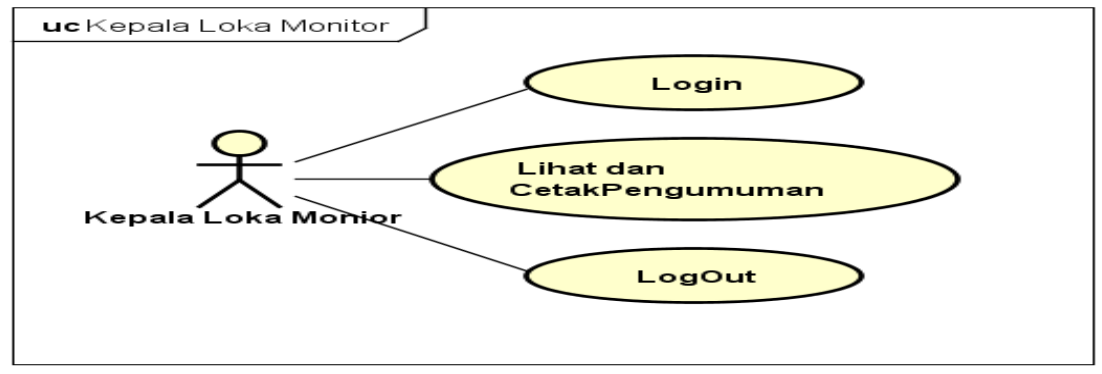

Gambar 4. Use Case Kepala Loka Monitor

\subsection{Metode Profile Matching}

Sebelum melakukan tahapan selanjutnya penulis melakukan analisa metode Profile Matching berdasarkan hasil wawancara dan observasi yang dilakukan pada tahapan sebelumnya yang nanti nya akan di terapkan pada sistem usulan, berikut tahapan-tahapan metode Profile Matching.

\subsubsection{Analisis Penilaian Karyawan Baru dengan Metode Profile Matching}

Untuk perhitungan penilaian karyawan baru yang mengunakan algoritma profile matching terlebih dahulu pengumpulan gap-gap pada tiap kriteria. perhitungan akan berbeda-beda, tergantung pada jumlah dan pengelompokkan kriteria yang ada pada aspek-aspek tersebut, seperti yang ditunjukkan pada tabel 1. 
Tabel 1. Kriteria

\begin{tabular}{cc}
\hline Aspek & Nama Kriteria \\
\hline T1 & Wawancara \\
T2 & Tes Tertulis \\
T3 & Tes Mcrosoft Word \\
T4 & Tes Microsoft Excel \\
T5 & Tes Keahlian \\
\hline
\end{tabular}

Persyaratan wajib karyawan untuk mendapatkan prestasi baik maka harus memiliki point penilaian yang besar. Penilaian yang besar harus memenuhi syarat wajib yang telah ditentukan oleh pihak perusahaan dan syarat tersebut adalah sudah ditetapkan dimana hasil point harus sama dengan atau lebih dari 3, point tersebut dapat dilihat melalui hasil selama calon karyawan menjalaini tes perusahan tersebut, dan untuk lebih jelasnya kriteria point ditunjukkan pada tabel 2.

Tabel 2. Nilai kriteria

\begin{tabular}{ccc}
\hline Range Nilai & Poin & Keterangan \\
\hline $0-20$ & 1 & sangat tidak baik \\
$30-40$ & 2 & tidak baik \\
$50-60$ & 3 & cukup baik \\
$70-80$ & 4 & Baik \\
$90-100$ & 5 & sangat baik \\
\hline
\end{tabular}

\subsubsection{Perhitungan Gap Penilaian}

Perhitungan pemetaan gap penilaian dimana yang dimaksud dengan Gap disini adalah selisih antara profil karyawan dengan profil perusahaan. Dimana nilai profile prusahaan telah di tentukan terlebih dahulu oleh perusahaan sebagai standar nilai kriteria yang diinginkan. Untuk perhitungannya dapat ditunjukkan pada rumus di bawah ini:

Gap = profil Calon Karyawan - Nilai Profil

Perhitungan Gap kompetensi dimana yang diambil ditunjukkan pada tabel 3.

Tabel 3. Perhitungan gap pada tiap kriteria

\begin{tabular}{ccccccc}
\hline No & Calon Karyawan & T1 & T2 & T3 & T4 & T5 \\
\hline 1 & Pelamar 1 & 4 & 4 & 4 & 3 & 4 \\
2 & Pelamar 2 & 5 & 4 & 3 & 4 & 5 \\
3 & Pelamar 3 & 1 & 1 & 1 & 1 & 1 \\
4 & Pelamar 4 & 2 & 2 & 2 & 2 & 2 \\
5 & Pelamar 5 & 2 & 3 & 2 & 1 & 4 \\
& Nilai Profil & 4 & 4 & 3 & 3 & 4 \\
1 & Pelamar 1 & 0 & 0 & 1 & 0 & 0 \\
2 & Pelamar 2 & 1 & 0 & 0 & 1 & 1 \\
3 & Pelamar 3 & -3 & -3 & -2 & -2 & -3 \\
4 & Pelamar 4 & -2 & -2 & -1 & -1 & -2 \\
5 & Pelamar 5 & -2 & -1 & -1 & -2 & 0 \\
\hline
\end{tabular}

Setelah didapatkan tiap gap masing- karyawan maka tiap karyawan diberi bobot nilai dengan patokan tabel bobot nilai gap seperti pada tabel 4 .

Tabel 4. Keterangan gap

\begin{tabular}{cccl}
\hline No & Selisih & Bobot Nilai & \multicolumn{1}{c}{ Keterangan } \\
\hline 1 & 0 & 5 & tidak ada selisih (dibutuhkan) \\
2 & 1 & 4,5 & Kompetensi kelebihan 1 level \\
3 & -1 & 4 & Kompetensi kurang 1 level \\
4 & 2 & 3,5 & Kompetensi kelebihan 2 level \\
5 & -2 & 3 & Kompetensi kurang 2 level \\
6 & 3 & 2,5 & Kompetensi kelebihan 3 level \\
7 & -3 & 2 & Kompetensi kurang 3 level \\
8 & 4 & 1,5 & Kompetensi kelebihan 4 level \\
9 & -4 & 1 & Kompetensi kurang 4 level \\
\hline
\end{tabular}


Setiap karyawan akan memiliki tabel Bobot seperti contoh-contoh tabel yang berada di bawah ini (contoh : Pelamar 1,Pelamar 2 , Pelamar 3, Peramal 4 dan Pelamar 5) seperti pada tabel 5:

Tabel 5. Tabel hasil bobot nilai

\begin{tabular}{cclccccc}
\hline No & Calon Karyawan & & $\boldsymbol{T 1}$ & $\boldsymbol{T} 2$ & $\boldsymbol{T 3}$ & $\boldsymbol{T 4}$ & $\boldsymbol{T 5}$ \\
\hline 1 & Pelamar 1 & Nilai Gap & 0 & 0 & 1 & 0 & 0 \\
& & Hasil bobot nilai & 5 & 5 & 4.5 & 5 & 5 \\
2 & Pelamar 2 & Nilai Gap & 1 & 0 & 0 & 1 & 1 \\
& & Hasil bobot nilai & 4.5 & 5 & 5 & 4.5 & 4.5 \\
3 & Pelamar 3 & Nilai Gap & -3 & -3 & -2 & -2 & -3 \\
& & Hasil bobot nilai & 2 & 2 & 3 & 3 & 2 \\
4 & Pelamar 4 & Nilai Gap & -2 & -2 & -1 & -1 & -2 \\
& & Hasil bobot nilai & 3 & 3 & 4 & 4 & 3 \\
5 & Pelamar 5 & Nilai Gap & -2 & -1 & -1 & -2 & 0 \\
& & Hasil bobot nilai & 3 & 4 & 4 & 3 & 5 \\
\hline
\end{tabular}

\subsubsection{Perhitungan dan Pengelompokan Core dan Secondary Factor}

Setelah menentukan bobot nilai gap untuk lima aspek tes penilaian calon karyawan baru yaitu aspek tes wawancara, tes tertulis, tes microsoft word, tes Microsoft excel dan tes keahlian. Kemudian kriteria dari lima aspek tersebut dikelompokkan menjadi 2 (dua) kelompok yaitu kelompok Core Factor dan Secondary Factor.

1) Core factor ( Faktor utama )

Core factor merupakan aspek (tes wawancara, tes tertulis, dan tes keahlian) yang menonjol atau yang diutamakan dan paling dibutuhkan. Untuk menghitung core factor digunakan rumus :

$$
N C F=\left(\sum N C(i, s, p)\right) /\left(\sum I C\right)
$$

\footnotetext{
Keterangan

$\mathrm{NCF} \quad$ : Nilai rata-rata core factor

$\mathrm{NC}(\mathrm{i}, \mathrm{s}, \mathrm{p})$ : Jumlah total nilai core factor

(Intelektual, Sikap kerja, Perilaku)

IC : Jumlah item core factor
}

2) Secondary Factor (Faktor Pendukung)

Secondary factor adalah item - item selain aspek yang ada pada core factor yang merupakan faktor pendukung dari faktor utama yang diinginkan. Untuk menghitung secondary factor digunakan rumus :

$$
N S F=\left(\sum N S(i, s, p)\right) /\left(\sum I S\right)
$$

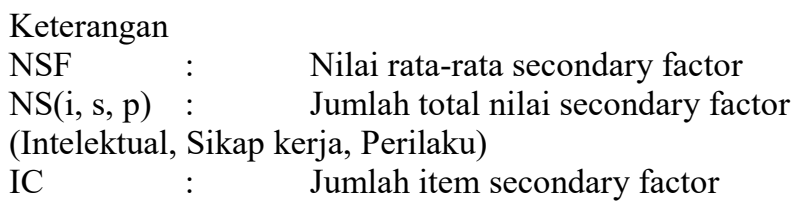

Perhitungan core factor dan secondary factor dilakukan dengan terlebih dahulu menentukan aspek mana saja yang menjadi core factor ( Faktor utama ) dari aspek-aspek yang telah ditentukan misalnya aspek 1, dan 2 dan aspek sisanya aspek 3, 4, dan 5 akan menjadi secondary factor (Faktor Pendukung). Berikut rumusnya:

Perhitungan Core Factor (Dituangkan dalam tabel 6)

NCF $\quad$ Pelamar $1=\left(\sum \mathrm{NC}(\mathrm{i}, \mathrm{s}, \mathrm{p})\right) /\left(\sum \mathrm{IC}\right)=(5+5) / 2$

NCF Pelamar $2=\left(\sum \mathrm{NC}(\mathrm{i}, \mathrm{s}, \mathrm{p})\right) /\left(\sum \mathrm{IC}\right)=(4.5+5) / 2$

NCF $\quad$ Pelamar $3=\left(\sum \mathrm{NC}(\mathrm{i}, \mathrm{s}, \mathrm{p})\right) /\left(\sum \mathrm{IC}\right)=(2+2) / 2$

NCF $\quad$ Pelamar $4=\left(\sum \mathrm{NC}(\mathrm{i}, \mathrm{s}, \mathrm{p})\right) /\left(\sum \mathrm{IC}\right)=(3+3) / 2$

$\mathrm{NCF} \quad$ Pelamar $5=\left(\sum \mathrm{NC}(\mathrm{i}, \mathrm{s}, \mathrm{p})\right) /\left(\sum \mathrm{IC}\right)=(3+4) / 2$

$$
\begin{aligned}
& =5 \\
& =4.75 \\
& =2 \\
& =3 \\
& =3.5
\end{aligned}
$$


Tabel 6. Nilai core factor

\begin{tabular}{ccccc}
\hline No & Calon Karyawan & T1 & T2 & Nilai Core Factor \\
\hline 1 & Pelamar 1 & 5 & 5 & 5 \\
2 & Pelamar 2 & 4.5 & 5 & 4.75 \\
3 & Pelamar 3 & 2 & 2 & 2 \\
4 & Pelamar 4 & 3 & 3 & 3 \\
5 & Pelamar 5 & 3 & 4 & 3.5 \\
\hline
\end{tabular}

Perhitungan Secondary Factor (Dituangkan dalam tabel 7)

$\begin{array}{llll}\text { NSF } & \text { Pelamar } 1=\left(\sum N S(\mathrm{i}, \mathrm{s}, \mathrm{p})\right) /\left(\sum \mathrm{IS}\right)=(4.5+5+5) / 3 & =4.83333333333333 \\ \text { NSF } & \text { Pelamar } 2=\left(\sum \mathrm{NS}(\mathrm{i}, \mathrm{s}, \mathrm{p})\right) /\left(\sum \mathrm{IS}\right)=(5+4.5+4.5) / 3 & =4.6666666666667 \\ \text { NSF } & \text { Pelamar 3 }=\left(\sum \mathrm{NS}(\mathrm{i}, \mathrm{s}, \mathrm{p})\right) /\left(\sum \mathrm{IS}\right)=(3+3+2) / 3 & =2.6666666666667 \\ \mathrm{NSF} & \text { Pelamar } 4=\left(\sum \mathrm{NS}(\mathrm{i}, \mathrm{s}, \mathrm{p})\right) /\left(\sum \mathrm{IS}\right)=(4+4+3) / 3 & =3.6666666666667 \\ \mathrm{NSF} & \text { Pelamar } 5=\left(\sum \mathrm{NS}(\mathrm{i}, \mathrm{s}, \mathrm{p})\right) /\left(\sum \mathrm{IS}\right)=(4+3+5) / 3 & =4\end{array}$

Tabel 7. Nilai secondary factor

\begin{tabular}{cccccc}
\hline No & Calon Karyawan & T3 & T4 & T5 & Nilai Secondary Factor \\
\hline 1 & Pelamar 1 & 4.5 & 5 & 5 & 4.8333333333333 \\
2 & Pelamar 2 & 5 & 4.5 & 4.5 & 4.6666666666667 \\
3 & Pelamar 3 & 3 & 3 & 2 & 2.6666666666667 \\
4 & Pelamar 4 & 4 & 4 & 3 & 3.6666666666667 \\
5 & Pelamar 5 & 4 & 3 & 5 & 4 \\
\hline
\end{tabular}

\subsubsection{Perhitungan Total Nilai}

Dari perhitungan setiap aspek diatas, berikutnya dihitung nilai total berdasarkan presentase dari core factor dan secondary factor yang diperkirakan berpengaruh terhadap penilaian tes tiap-tiap calon karyawan baru. Penetapan persentasi untuk rumus nilai total aspek adalah tergantung masing - masing perusahaan yang memakai. Namun pada umumnya persentasi yang diberikan $60 \%$ untuk core factor ( faktor utama ) dan $40 \%$ untuk secondary factor ( faktor pendukung ). Untuk perhitungannya dapat dilihat pada rumus dibawah ini :

$$
N(i, s, p)=(x) \% N C F(i, s, p)+(x) \% N S F(i, s, p)
$$

$\begin{array}{lll}(\mathrm{x}) \% & : & \text { Nilai persen } \\ \text { NCF } & : & \text { Nilai rata-rata core factor } \\ \text { NSF } & : & \text { Nilai rata-rata secondary factor }\end{array}$

Perhitungan nilai total dengan nilai persentase yang telah ditetapkan adalah $60 \%$ untuk core factor dan $40 \%$ untuk secondary factor adalah seperti berikut ini:

\begin{tabular}{|c|c|c|c|}
\hline NS 001 & $=$ & $(60 \% \times 5)+(40 \% \times 4.8333333333333)$ & $=4.9$ \\
\hline NS 002 & $=$ & $(60 \% \times 4.75)+(40 \% \times 4.6666666666667$ & \\
\hline NS 003 & $=$ & $(60 \% \times 2)+(40 \% \times 2.6666666666667)$ & $=2.4$ \\
\hline NS 004 & $=$ & $(60 \% \times 3)+(40 \% \times 3.6666666666667)$ & $=3.4$ \\
\hline NS 005 & $=$ & $(60 \% \times 3.5)+(40 \% \times 4)=3.8$ & \\
\hline
\end{tabular}

Tabel 8. Tabel total nilai

\begin{tabular}{cccc}
\hline Calon Karyawan & Core Factor & Secondary Factor & NS \\
\hline Pelamar 1 & 5 & 4.8333333333333 & 4.9 \\
Pelamar 2 & 4.75 & 4.6666666666667 & 4.7 \\
Pelamar 3 & 2 & 2.6666666666667 & 2.4 \\
Pelamar 4 & 3 & 3.6666666666667 & 3.4 \\
Pelamar 5 & 3.5 & 4 & 3.8 \\
\hline
\end{tabular}

\subsubsection{Entity Relationship Diagram}

Diagram berikut menunjukkan hubungan antar data dari sistem usulan yang terdiri dari 8 entitas yaitu Pelamar, Notifikasi, Tes, Konversi, Nilai, Bobot, Kriteria dan Sub_kriteria beserta atributnya, seperti yang ditunjukkan pada gambar 5 . 


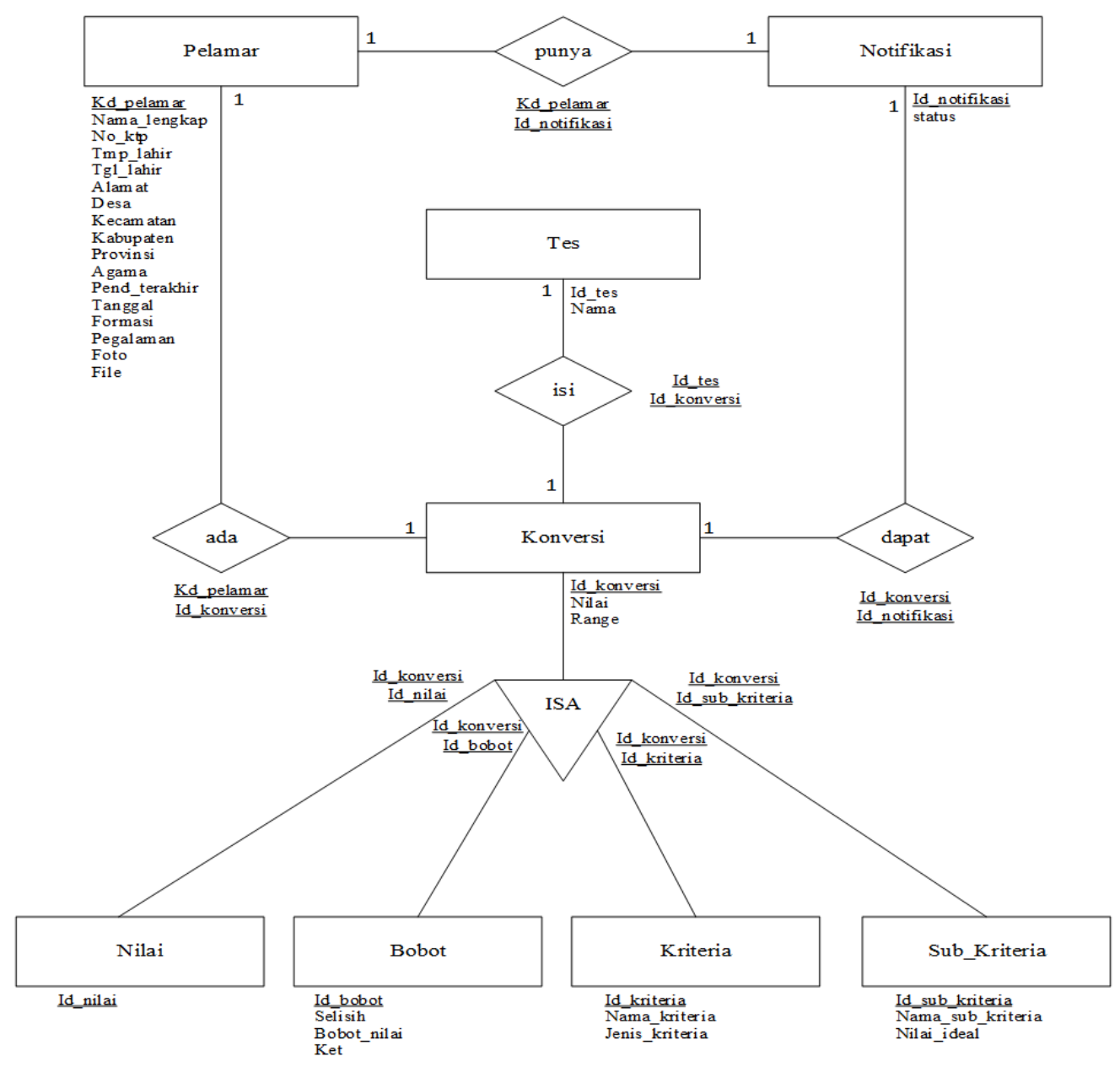

Gambar 5. Entity Relationship Diagram (ERD)

\section{KESIMPULAN}

Perhitungan nilai total yang didapatkan untuk calon karyawan baru Pelamar 1 adalah 4.9, Pelamar 2 adalah 4.7, Pelamar 5 adalah 3.8, Pelamar 4 adalah 3.4 Dan Pelamar 3 adalah 2.4 dari hasil nilai total yang diperoleh, calon karyawan baru dengan Pelamar 1 adalah 4.9 sebagai calon karyawan mendapatkan hasil yang paling baik. Rangking dapat dilakukan dengan menggunakan pengurutan dari nilai terbesar sampai nilai terkecil.

\section{DAFTAR PUSTAKA}

[1] A. Dennis, B. H. Wixom dan R. M. Roth, 2012, System Analysis and Design 5th edition, New Jersey: John Wiley \& Sons, Inc.

[2] Anhar. 2010. PHP \& MySQL Secara Otodidak. Jakarta: PT TransMedia

[3] Deny Adhar (2014), Sistem Pendukung Keputusan Pengangkatan Jabatan Karyawan pada PT.Ayn dengan Metode Profile Matching STMIK POTENSI UTAMA, Medan.

[4] Gaol, L, Jimmy. 2008. Sistem Informasi Manajemen Pemahaman dan Aplikasi. Jakarta : Penerbit PT Grasindo.

[5] Gunawan, Dkk, 2016, Pengembangan Spk Penerimaan Karyawan Dengan Menggunakan Profile Matching, Studi Kasus: Pt X, Seminar Nasional Teknologi Informasi Dan Multimedia, ISSN : 2302-3805

[6] Hardi Zulhidayat (2016), Perancangan Sistem Pendukung Keputusan Rekrutmen Pegawai Baru Pada Cv. Konsuil Pangkalan Bun Menggunakan Metode Profile Matching, Universitas Dian Nuswantoro.

[7] Hartatik (2013), Analisis Dan Perancangan Seleksi Pemilihan Pegawai Untuk Suatu Jabatan Menggunakan Metode Profile Matching, STMIK AMIKOM Yogyakarta.

[8] Kusrini., 2007, Konsep dan Aplikasi Sistem Pendukung Keputusan, Andi Offset, Yogyakarta.

[9] Nina Sherly (2013), Penerapan Metode Profile Matching Dalam Sistem Pendukung Keputusan Pemberian Bonus Karyawan (Studi Kasus: Pt. Sanghyang Seri Persero), STMIK Budidarma Medan.

[10] R. Prasetyo Agung Nugroho, Purwanto (2015), Rancangan Sistem Pendukung Keputusan Penerimaan Pegawai Menggunakan Metode Profile Matching, STMIK AMIKOM Yogyakarta.

[11] Tata sutabri, 2012 Analisa Sistem Informasi, Andi Yogyakarta. 